\title{
The effects of information technology and operation performance on service supply chain management practices with moderating effect of capital owners
}

\author{
Zainal Abidin ${ }^{\text {a* }}$
}

${ }^{a}$ Faculty of Economics and Business, Universitas Mulawarman, Samarinda, Indonesia

\section{H R O N I C L E}

Article history:

Received October 28, 2020

Received in revised format

January, 15, 2021

Accepted February 42021

Available online

February 42021

Keywords:

Information technology

Service supply chain

management practices

Operational performance

Capital owner

\section{A B S T R A C T}

\begin{abstract}
The objective of this study is to analyze and review the influence of government regulations and information technology on the operational performance of local television stations in East Java with service supply chain management practices as the mediator variable and capital owner's intervention as the moderator variable. The data of exploratory research was collected through questionnaires distributed to twenty-nine local televisions stations, selected through saturated sampling method from a population of local television stations in East Java, and was analyzed using structural equation modeling. The finding of this study reveals that government regulations and information technology significantly influence the operational performance of local television stations with service supply chain management (SCM) practices as the mediator variable, which means that better government regulations and better information technology are analogous with the importance for the improvement of local television stations operational performance. Capital owner intervention weakens service SCM practices on operating performance and has a direct and immediate effect on reducing the operational performance of local television stations. The practical implications of this study signify the understanding that service SCM practices is an important concept in enhancing the operational performance. Capital owner's intervention weakens service SCM practices on operating performance of local television stations.
\end{abstract}

\section{Introduction}

Television is a broadcasting technology and as a mass media and network station system from an industrial perspective. The effectiveness of the use of technology as a medium of coordination or integration between and within organizations has received much attention, but there are still many that lead to unclear conclusions (Narasimhan and Kim, 2002). Positive views of Sohal and Lionel, (1993) who examined the influence of the role of information technology on 530 companies in Australia and found that the use of information technology was positively related to organizational performance. Bender, (1986); Barua and Lee, (1997) also state that there is a weak relationship between information technology on business performance. A number of other researchers also state that improving information exchange can have a large influence on company efficiency and performance (Gustin et al., 1994; Daugherty et al., 1994; Bowersox and Closs 1996; Closs and Savitskie, 2003). Information technology connects the supply chain partnership, such as manufacturing, retailers, transportation companies and distributors. (Vaidyanathan, 2005). In addition, information technology has the potential to not only increase operational efficiency and effectiveness, but is a way to change business competition (MCFarlan and McKenny, 1983). Porter and Miller (1985) demonstrate that information technology is able to integrate value chain activities and increase competitive advantage. Benjamin et al. (1984); Cash and Konsynki (1985). Some literature shows that information technology influences competitive advantage (Bharadwaj, 2000; Santhanam and Hartono, 2003). Moreover,

* Corresponding author

E-mail address: zainal.abidin@feb.unmul.ac.id (Z.Abidin)

C 2021 by the authors; licensee Growing Science.

doi: $10.5267 /$ j.uscm.2021.2.002 
the empirical evidence presented (Peng et al., 2015; Li et al., 2005, 2006) shows that the higher the level of SCM practice, the higher the competitiveness and the higher the performance of the organization. In contrast, research conducted by MoraMonge (2007) found that supply chain integration does not affect organizational benefits as measured by business efficiency and competitiveness.

Issues related to physical movement of goods (tangible products) and information flows and business processes seem to dominate the empirical basis of supply chain research. Supply chain is widely applied to the manufacturing industry, even though the service industry is developing and has become the engine of growth in the world economy (Zhang \& Chen, 2015). In fact, many manufacturing industries get their revenues from managed service units such as IBM and GM companies. So, the supply chain service (SSC) is a new research topic for academics. This research starts from the research proposed by Elram which states that SCM is also relevant for services (intangible products) (Ellram et al., 2004). Lindskog and Wennberg (2002) state that the use of new technology increases the efficiency of the supply chain and improves the overall performance of the company. Li et al. (2005), Bayraktar (2009), Chin et al. (2004), Harsasi (2014) report that there is a positive relationship between the use of Information System technology and the level of SCM practices and company performance. The results of the above research, the researchers view that operating performance will increase if supported by the practice of SCM and SCM will run smoothly if supported by the role of information technology of local television broadcasters. Operation performance as the final goal will be achieved. In the operational practices of broadcasters there are intervention of capital owners as reported by Nugroho et al. (2012a) and Rianto (2007) which state that there is an influence of capital owner intervention on the operating process and performance of broadcasters.

\section{Literature Review and Hypothesis}

\subsection{Government Regulation on Operational Performance}

Barth et al. (2000) found that government regulations affect operational performance in commercial banks in developed countries. The results of research conducted by Shaw et al., 2005. Finding a positive relationship between government regulation and performance. In contrast to the findings of several other researchers, such as: Chen et al. (2005) found that the higher the government's interference with a Direct Government-Controlled Company (DGCC) company, the lower the company's performance. Sun and Tong (2003) also found that government interference had a negative effect on company performance in the China Exchange.

\section{$\mathrm{H}_{1}$. Influential Government Regulation directly improves operating performance.}

\subsection{Information Technology on Operational Performance}

Peng et al. (2015), found that only coherent integration of Information Technology capabilities and the ability of the company's business processes to improve supply chains can improve company performance. Sohal and Lionel (1993) examined the effect of the role of information technology on 530 companies in Australia and found that the use of information technology was positively related to organizational performance. Likewise, with the Bender (1986) study; Barua and Lee (1997) who also stated that there was a weak relationship between information technology and overall business performance. Empirical research on logistical barriers in China shows that 6 areas of logistics management are obstacles to strategic alliances: purchasing, transportation services, processing documentation/orders, warehousing services, inventory control and import/export services. In detail, poor logistics services include a lack of transportation from reliable shipments, insufficient transportation infrastructure and poor communication infrastructure. These obstacles interfere with improvements in company performance (Han, 2009). Previous research found that the influence of information technology capabilities on all performance remains ambiguous. This means that there is not enough research investigation on the mediation mechanism that connects information technology and performance. The direct influence of specific information technology capabilities, such as analytical systems with collaboration between companies is under-researched (Rai et al., 1997, 2006). Likewise, the effectiveness of using technology as a medium for coordination or integration between organizations has received much attention, but there are still many that lead to less clear conclusions (Narasimhan \& Kim, 2002). Some researchers have also stated that improving information exchange can have a large influence on overall efficiency and performance of the company (Bowersox \& Closs, 1996; Close \& Savitskie, 2003; Daugherty et al., 1995; Gustin et al., 1994; Ives \& Jarvenpaa, 1991; Jie et al., 2007).

$\mathrm{H}_{2}$. Information technology is capable of acting directly to improve operating performance.

\subsection{SCM Service Practices on Operational Performance}

Soo (2006) found a significant effect when testing the causal link between SCM practices and company performance. Further research on SCM practices related to avoiding uncertainty in achieving performance is useful in developing a framework for linking supply chain integration strategies with competitive strategies to improve company performance. Li et al. (2006) found that the higher the level of SCM practice, the higher organizational performance. Frohlich and Wesbrook 
(2002) found that supply chain integration improves operational performance, namely delivery time, and transaction costs. Gonzalez-Benito (2007) found that the practice of SCM affects operational performance in a purchasing perspective. Harland (1997) found that SCM practices have an impact on supply chain operational performance. This shows that companies with higher levels of SCM practice have higher levels of operational performance, as in the following hypothesis:

\section{$\mathrm{H}_{3}$. The SCM service practice is able to improve operating performance.}

\subsection{Government Regulations, Information Technology, SCM Service Practices and Operational Performance}

Changes in environmental elements including government regulation and information technology have an impact on operating performance. The impact of the policy can be positive or negative as well as the direction and stability of policy factors making consideration of company management in formulating strategies and ultimately impacting performance. Researchers have proven a positive relationship between supply chain collaboration and performance (for example: Rodrigues et al., 2004; Sanders \& Premus, 2005; Stank et al., 2001). As for the results of Bayraktar et al., (2009) research also reported a positive relationship between the use of information systems and technology in SCM practices and company performance using samples of metal manufacturing industries in Turkey. Research on the use of information technology systems to support SCM, the results clearly show that the use of new technologies can improve the efficiency of the supply chain and improve overall company performance (Lindskog and Wennberg, 2002). There is a theoretical basis that there is a direct influence of information technology on organizational performance, and the practice of service SCM influences organizational performance, and information technology influences SCM service practices.

$\mathrm{H}_{4}$. The SCM service practice mediates the impact of government regulations on improving operating performance. $\mathrm{H}_{5}$. The SCM service practice mediates the effect of information technology in improving operating performance.

\subsection{Capital Owner Intervention (COI) Moderating SCM Service Practices to Operational Performance}

Owner intervention in terms of programs or broadcast content is carried out directly and indirectly Direct intervention in the form of program policies and program production, indirect intervention through the placement of certain people and contracts with third parties to establish program policies and editorials for broadcast programs. This capital owner's intervention ultimately makes the resulting content not neutral (Rianto, 2014; Ou, 2010). Nugroho et al. (2012b) found that the agenda setting is also a scheme in which media owners can intervene on media content. The agenda setting and owner intervention are usually listed in the media group's financial plan. However, in today's media, the owner himself leads the meeting to determine the agenda setting; this makes capital interventions and media owners go directly to content production. This description shows the connection between media companies and their organizational/political interests, as well as the business interests of their owners. News production must include the owner's business and political interests in the production of content, including public news. All media channels owned by these media groups must have one main perspective in delivering news, especially news related to the interests of the owner.

$\mathrm{H}_{6}$. The lower the Capital Owner Intervention, the higher the influence of Service SCM practices on improving operational performance.

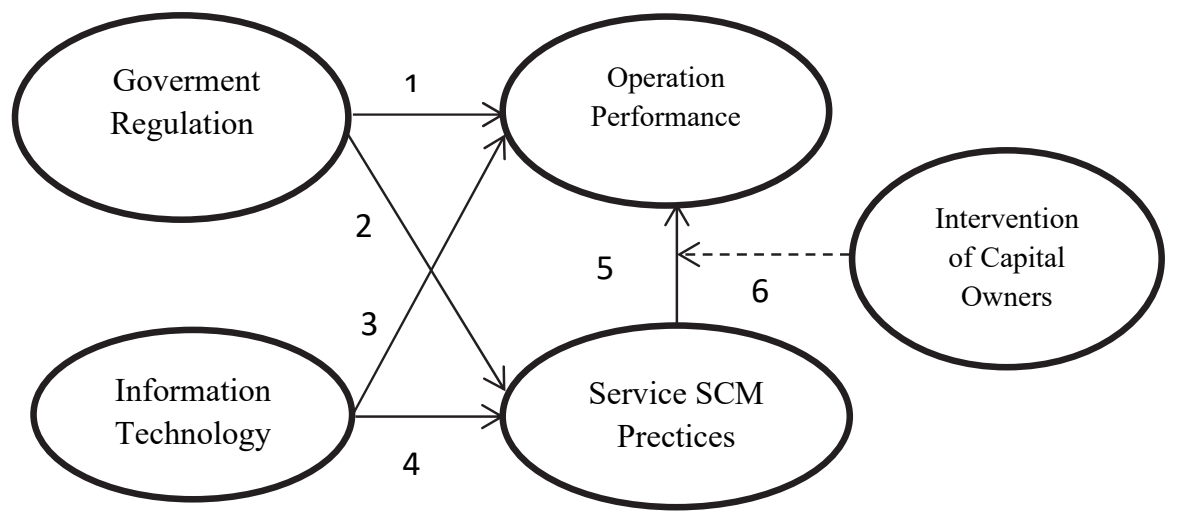

Fig. 1. Conceptual Framework

\section{Research methods}

This study was designed using an explanatory research approach with data collection carried out in one stage (one short study) or in a cross-section. The subjects of this study were local television broadcasters and the research locations were East Java Province. The population of this study is a local television broadcasting institution in the East Java province. The 
technique of sampling this study using saturated sampling or census. Saturated sampling or census techniques are used with consideration of the relatively small population of this study, which is as many as 29 local television stations.

To measure the validity and reliability of variable constructs per indicator and per item a pre-test questionnaire was conducted to the local television broadcasting manager. Government regulation is defined as a series of actions proposed by a person, group or government in a particular scope by showing obstacles and opportunities for implementing the proposed policy in order to achieve certain goals. This variable indicator adopts Klimkiewicz (2010). The obstacles are content creation, content packaging, content distribution and consumer protection. Turban (2005) states that information technology is an information system that carries out activities to collect, process, store, and disseminate information for specific purposes, which include: hardware, software, databases and networks (network). For services supply chain management Practices, it is defined as activities carried out by organizations to increase management effectiveness towards their supply chain. It consists of 6 dimensions used to access managers' perceptions of practical use, namely: capacity management, supplier relationship management, customer relationship management, information flow management, demand management, cash flow (Elram et al., 2004). Operational performance is defined as the company's perception of the growth in the level of supply chain integration towards the growth of potential profits. Consisting of delivery time, process flexibility, cost reduction, product innovation and product quality (Terziovski \& Samson, 1999). Lastly, the capital owner's intervention is defined as the interests of the capital owners of the program content that is broadcast by local television private broadcasters. The development of contract intervention by capital owners refers to the results of Nugroho's 2012 research and 2014 Praise R. These interests cover two things, namely the owner's political interests as the owner's image of public opinion of the owner's business. All items were measured with a 5-point Likert scale measurement.

\section{Empirical results and discussion}

Structural equation modeling with partial least square (PLS) is used to test hypotheses because their abilities explain independent and dependent multiple. This study used a PLS SEM model and was processed with WarpPLS version 5 to evaluate the research model. Testing the hypothesis through two stages, namely testing the outer model and testing the inner model. The outer model test aims to determine the value of the latent variable correlation, cross loadings, validity and construct reliability and R Square (R2). Inner model testing aims to determine the value of path coefficient, inner T-statistic model, and total effect value that shows the level of variation in changes in the independent variable on the dependent variable (Root et al., 2011; Hartono and Abdillah, 2009).

\section{Table 1}

Goodness of Fit (GoF) Index

\begin{tabular}{lll}
\hline Variable & Communality & $\mathrm{R}^{2}$ \\
\hline Government Regulation & 0.832 & - \\
Information Technology & 0.648 & - \\
Service SCM practice & 0.548 & 0.692 \\
Operational Performance & 0.655 & 0.826 \\
Capital Owner Intervention & 0.850 & - \\
Service SCM $\times$ Capital Owner Intervention & 0.385 & - \\
\hline Total & 3.918 & 1.518 \\
Average & 0.653 & 0.759 \\
Goodness of Fit (GoF) Index & 0.704 & \\
\hline
\end{tabular}

The suitability of the model can also be calculated using the index of goodness of fit. The index of goodness of fit (GoF) is defined as the geometric mean or root of the average communality and the mean $\mathrm{R}^{2}$ for all endogenous constructs (Tenenhaus et al. 2005). The GoF index (Akter et al., 2011) shows predictive power over the overall model. GoF values have intervals between 0 and 1. Hypothesis testing is based on the results of the PLS SEM model analysis which contains all the supporting variables of the hypothesis test. The PLS model with the addition of the SCM service variable as a mediating variable and the intervention of the capital owner as a moderator variable explains that the addition of variables will contribute additionally as an explanation of operating performance. The hypothesis model is illustrated in Fig. 2. In this model there is a number of information obtained in the results of the analysis. In accordance with the correlation coefficient between the variables described in Table 1, the correlation coefficient of government regulation on operating performance is smaller when compared to the correlation coefficient of information technology on service SCM practices.

Table 2

Path Coefficient Test Results in the Inner Model

\begin{tabular}{|c|c|c|c|}
\hline Correlation & Path coefficient & Standard Deviation & $\mathrm{P}$ \\
\hline Government regulation to operating performance & 0.070 & 0.179 & 0.350 \\
\hline Information technology to operating performance & 0.279 & 0.161 & 0.047 \\
\hline SCM service to operating performance & 0.405 & 0.151 & 0.006 \\
\hline Government regulation to service SCM practices & 0.340 & 0.156 & 0.019 \\
\hline Information technology to service SCM practices & 0.620 & 0.136 & $<0.001$ \\
\hline Capital owner intervention to operating performance & -0.300 & 0.160 & 0.035 \\
\hline Interaction $*$ service interaction to operating performance & -0.017 & 0.184 & 0.464 \\
\hline
\end{tabular}




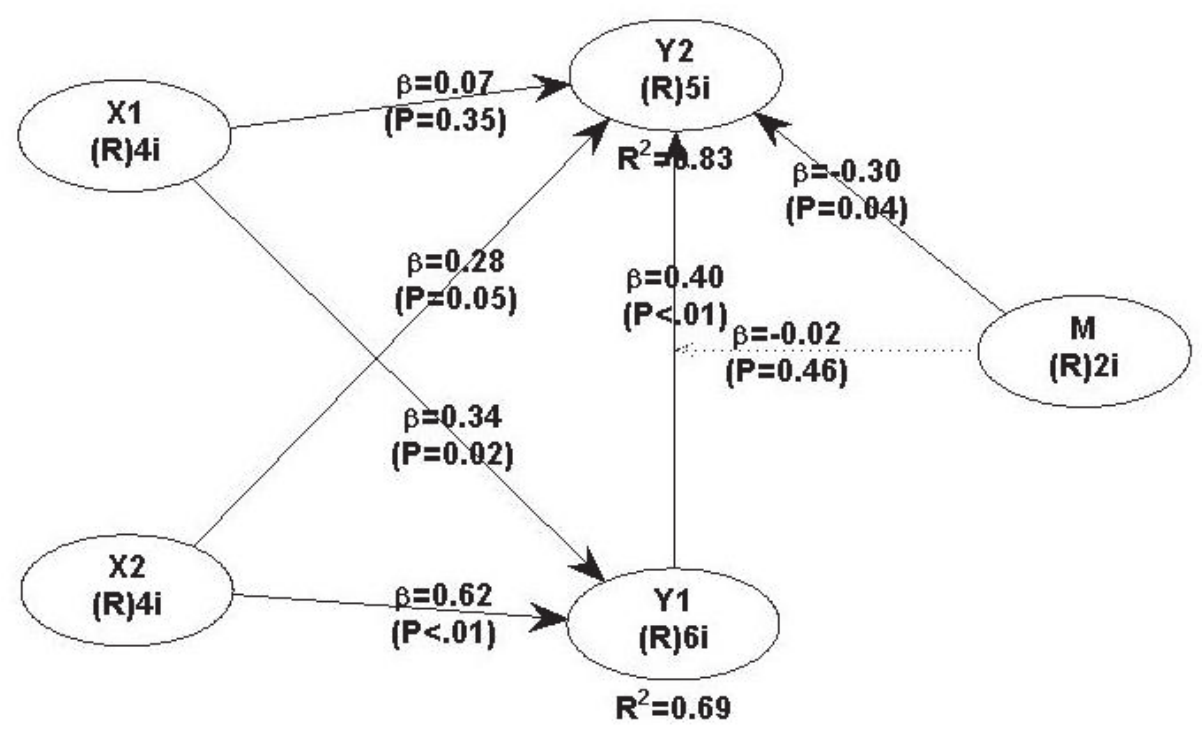

Fig. 2. Hypothesis Model

This result explains that the role of information technology is more needed to support SCM services. The path coefficient of information technology on SCM service of 0.620 is the largest when compared to other path coefficients. Government regulation on operating performance has a coefficient with a positive direction. The calculation results show that the path coefficient of $0.070(\mathrm{p}>0.05)$ gives a decision that government regulation has no significant effect on operating performance. The results of this analysis state that the low level of government regulation support will not encourage local television to improve operating performance. This is in accordance with previous research. Chen et al., (2005) found that the higher the government's interference with a company (direct Government-Controlled Company), the lower the company's performance. Sun and Tong, (2003) found that government interference through ownership of companies in the Chinese market had a negative effect on company performance. Thus, the findings of this study are not in line with the findings of Chen et al. (2005) and Sun and Tong, (2003), namely that government regulation has a negative influence on the performance of local television operations.

Information technology on operating performance has a coefficient with a positive direction. The calculation results show that the path coefficient is $0.620(\mathrm{p}<0.05)$ giving a decision that information technology has a significant effect on operating performance. The results of this analysis state that the use of information technology in accordance with current needs will encourage local television to improve operating performance. Sohal and Lionel (1993) found that the use of information technology was positively related to operating performance. Thus, the findings of this study are in line with the findings of Sohal and Lionel (1993), namely the use of information technology has a positive influence on improving operating performance. This finding is also in line with the findings of Wang and Lee (2013) that information technology alliances and information sharing are directly related and have a positive effect on the performance of supply chain operations. Service SCM on operating performance has a coefficient with a positive direction. The calculation results show that the path coefficient is $0.405(\mathrm{p}<0.05)$ giving a decision that information technology has a significant effect on operating performance. The results of this analysis state that implementing a good SCM service will encourage local television to improve operating performance. This finding also supports the findings of Rodrigues et al. (2004); Sanders and Primus, (2005); Stank et al., (2001), that is, there is a positive relationship between supply chain collaboration and performance. But it contradicts the findings of Landgren et al. (2009); that is, external integration has no significant effect on company performance. Government regulation of SCM services has a coefficient with a positive direction. The calculation results show that the path coefficient is $0.340(\mathrm{p}<0.05)$ giving a decision that government regulation has a significant effect on the SCM service. The results of this analysis state that government regulations will provide a positive boost to local television to improve SCM services. The findings of this study are in accordance with the E-S-P (Environment-Strategy-Performance) concept, that government regulation and service SCM practices have a relationship with operating performance. This finding is also in line with the findings of Lindgreen et al. (2009) namely, the implementation of high supply chain integration can improve operating performance. The difference between this research and previous research is to place service SCM as a strategy as a mediation of government regulations on operating performance. Another difference is the measurement of SCM service practices using special SCM measurements in the service industry developed by Elram et al. (2004).

Information technology for SCM services has a coefficient with a positive direction. The calculation results show that the path coefficient is $0.620(\mathrm{p}<0.05)$ giving a decision that information technology has a significant effect on the SCM service. 
The results of this analysis state that the use of information technology in accordance with current needs will encourage local television to improve SCM services. The findings of this study are in accordance with the concept of E-S-P (Environment-Strategy-Performance), that the technological environment and service practices of SCM have a relationship with operating performance. This finding is also in line with the findings of Lindgreen et al. (2009) namely, the implementation of high supply chain integration can improve operating performance and Li et al., (2004); Bayraktar et al. (2009); Harsasi M. (2014); Peng et al. (2015), namely there is a positive and strong correlation between the direct relationship between the use of information technology systems in SCM practices and operational performance.

The intervention of capital owners to operating performance has a coefficient with a negative direction. The calculation results show that the path coefficient of $-0.300(p<0.05)$ gives a decision that the intervention of capital owners has a significant effect on operating performance. The results of this analysis state that the high intervention of capital owners in the company will hamper local television in improving operating performance. These findings are in line with the findings of Nugroho et al. (2012) and Rianto (2014) that is, the intervention of capital owners has a negative effect on local television content in media pluralism. In contrast to Nugroho et al. (2012) and Rianto (2014) conducted qualitatively by informants are business actors on national television, while this research was conducted with different samples and respondents, namely on local television. The interaction of service SCM with the intervention of capital owners on operating performance has a coefficient with a negative direction. The calculation results show that the path coefficient of -0.017 (p>0.05) gives a decision that the interaction of SCM service with the intervention of capital owners has no significant effect on operating performance. The results of this analysis state that the high intervention of capital owners on local television tends to inhibit local television in improving operating performance. The results of the calculation show that the inner model Rm 2 value is 0.946 which means that the research model has a high model match. The accuracy of the model of $94.6 \%$ explained that the contribution of the model to explain the structural relationship of the five variables studied was $94.6 \%$ and the remainder was explained by other variables not involved in the model.

\section{Conclusions}

Based on the results of the discussion and research findings, several conclusions of this research can be presented as follows. Government regulations provide a low impetus to improving the performance of local television operations. The most important push is content creation. These results indicate that the greater the restrictions on government regulations, especially the creation of television show content, will improve the performance of local television operations. The use of high technology can improve operating performance. These results indicate that the use of high technology, especially high networks will produce better performance, especially product innovation performance of local television operations. Service SCM practices improve operating performance. These results indicate that good service SCM practices, especially supplier relationship management, improve the performance of local television. Service SCM practices as a mediation between government regulation and operating performance can provide an important and real role in supporting the improvement in the performance of local television operations in East Java. The limitation of this study is that government regulations on content control have not included government regulations on network stations and the object of research on local television in East Java with local television manager respondents thus limiting the ability to generalize the findings of this study on local television in other regions. The analysis of this study is based on surveys in the presentation of relationship analysis in a certain period. Since the existence of the stations is dynamic, further studies that assess the changes in the linkages among variables analyzed in this study are needed. Based on the results of this study it can be suggested for future researchers. This research still does not include local culture as an approach to the local community, which is a distinctiveness and strength of the competitiveness of local television. Future research should discuss local television collaboration with national television, add innovation strategies, and broader locations as research objects.

\section{References}

Akter, S., D'Ambra, J., \& Ray, P. (2011). An evaluation of PLS based complex models: the roles of power analysis, predictive relevance and GoF index. Proceedings of the Seventeenth Americas Conference on Information Systems, Detroit, Michigan August 4th - 7th.

Barth, J. R., Caprio Jr, G., \& Levine, R. (2001). Banking systems around the globe: do regulation and ownership affect performance and stability? In Prudential supervision: What works and what doesn't (pp. 31-96). University of Chicago Press.

Barua, A., \& Lee, B. (1997). The information technology productivity paradox revisited: A theoretical and empirical investigation in the manufacturing sector. International journal of flexible manufacturing systems, 9(2), 145-166.

Bayraktar, E., Demirbag, M., Koh, S. L., Tatoglu, E., \& Zaim, H. (2009). A causal analysis of the impact of information systems and supply chain management practices on operational performance: evidence from manufacturing SMEs in Turkey. International Journal of Production Economics, 122(1), 133-149.

Bender, D. H. (1986). Financial impact of information processing. Journal of Management Information Systems, 3(2), 2232.

Benjamin, R.I., Rockart, J.F., Scott Morton, M.S. \& Wyman, J. (1984). Information technology: a strategic opportunity, Sloan Management Review, 25 (3), 3-10. 
Bharadwaj, A. S. (2000). A resource-based perspective on information technology capability and firm performance: an empirical investigation. MIS quarterly, 169-196.

Bowersox, D. J., \& Closs, D. J. (1996). Logistical management: the integrated supply chain process. McGraw-Hill College.

Cash, J. I., \& Konsynski. B.R. (1985). Redraws Competitive Boundaries. Harvard Business Review, 63(2), $134-142$.

Chen, S. K., Chen, X., Lin, B. X., \& Zhong, R. (2005). The impact of government regulation and ownership on the performance of securities companies: Evidences from China. Global Finance Journal, 16(2), 113-124.

Chin, K. S., Tummala, V. R., Leung, J. P., \& Tang, X. (2004). A study on supply chain management practices. International Journal of Physical Distribution \& Logistics Management, 34(6), 505-524.

Closs, D. J., \& Savitskie, K. (2003). Internal and external logistics information technology integration. The International Journal of Logistics Management, 14(10), 63-76.

Daugherty, P. J., Ellinger, A. E., \& Rogers, D. S. (1995). Information accessibility. International Journal of Physical Distribution \& Logistics Management, 25(1), 4-17.

Daugherty, P.J. (1994). Strategic information linkage. in Robeson, J.F. and Copacino, W.C. (Eds), The Logistics Handbook, The Free Press, New York, NY, pp. 757-69.

Ellram, L. M., Tate, W. L., \& Billington, C. (2004). Understanding and managing the services supply chain. Journal of Supply Chain Management, 40(3), 17-32.

Gustin, C. M., Stank, T. P., \& Daugherty, P. J. (1994). Computerization: supporting integration. International Journal of Physical Distribution \& Logistics Management, 24(10), 11-16.

Harsasi, M. (2015). Mediating Role of Strategic Supply Management on Performance. Agriculture and Agricultural Science Procedia, 3, 89-94.

Hartono, J., \& Abdillah, W. (2009). Konsep dan aplikasi PLS (Partial Least Square) untuk penelitian bisnis. BPFEYogyakarta.

Ives, B., \& Jarvenpaa, S. L. (1991). Applications of global information technology: key issues for management. Mis Quarterly, 33-49.

Jie, F., Parton, K., \& Cox, R. (2007). Supply Chain Practice, supply chain performance indicators and competitive advantage. Journal of Management. 28 (3): 413-446.

Kim, S. W. (2006). Effects of supply chain management practices, integration and competition capability on performance. Supply Chain Management: An International Journal, 11(3), 241-248.

Klimkiewicz, B. (Ed.). (2010). Media freedom and pluralism: media policy challenges in the enlarged Europe. Central European University Press.

Li, S., Ragu-Nathan, B., Ragu-Nathan, T. S., \& Rao, S. S. (2006). The impact of supply chain management practices on competitive advantage and organizational performance. Omega, 34(2), 107-124.

Li, S., Rao, S. S., Ragu-Nathan, T. S., \& Ragu-Nathan, B. (2005). Development and validation of a measurement instrument for studying supply chain management practices. Journal of operations management, 23(6), 618-641.

Lindgreen, A., Hingley, M., Han, J., Trienekens, J. H., \& Omta, S. O. (2009). Integrated information and logistics management, quality management and firm performance of pork processing industry in China. British Food Journal. 111(1), 9-25.

Lindskog, H., \& Wennberg, H. (2002). Learning from" Big Brother": Public Sector E-Commerce as a Role Model for Swedish Industry. Quarterly Journal of Electronic Commerce, 3, 211-222.

McFarlan, F. W., \& McKenney, J. L. (1983). Corporate information systems management: The issues facing senior executives. Irwin Professional Publishing.

Monczka, R. M., Trent, R. J., \& Handfield, R. B. (2002). Purchasing and supply chain management. South-Western Pub.

Mora-Monge, C. A. (2007). A contingency model of web-based EC uses: A supply chain approach (Doctoral dissertation, University of Toledo).

Narasimhan, R., \& Kim, S. W. (2002). Effect of supply chain integration on the relationship between diversification and performance: evidence from Japanese and Korean firms. Journal of operations management, 20(3), 303-323.

Nugroho, Y., Putri, D. A., \& Laksmi, S. (2012a). Memetakan lansekap industri media kontemporer di Indonesia. Centre for Innovation Policy and Governance. Jakarta.

Nugroho, Y., Syarief, S. S., Suhanda, I., \& Hitipiew, V. (2012b). Melampaui aktivisme click?: media baru dan proses politik dalam Indonesia kontemporer. Friedrich-Ebert-Stiftung (FES).

Ou, C. S., Liu, F. C., Hung, Y. C., \& Yen, D. C. (2010). A structural model of supply chain management on firm performance. International Journal of Operations \& Production Management, 30(50, 526-545.

Peng, J., Quan, J., Zhang, G., \& Dubinsky, A. J. (2016). Mediation effect of business process and supply chain management capabilities on the impact of IT on firm performance: Evidence from Chinese firms. International Journal of Information Management, 36(1), 89-96.

Porter, M. E., \& Millar, V. E. (1985). How information gives you competitive advantage. Harvard Business Review, Vol. 63 No. 4, pp. 149-60.

Rai, A., Patnayakuni, R., \& Patnayakuni, N. (1997). Technology investment and business performance. Communications of the ACM, 40(7), 89-97.

Rai, A., Patnayakuni, R., \& Seth, N. (2006). Firm performance impacts of digitally enabled supply chain integration capabilities. MIS quarterly, 225-246.

Rianto, P. (2007). Pers Indonesia Kontemporer: Antara Profesionalisme dan Tanggung Jawab Sosial. Yogyakarta: PKMBP 
Sanders, N. R., \& Premus, R. (2005). Modeling the relationship between firm IT capability, collaboration, and performance. Journal of business logistics, 26(1), 1-23.

Santhanam, R., \& Hartono, E. (2003). Issues in linking information technology capability to firm performance. MIS quarterly, 125-153.

Sekaran, U. (2003). Research Methods for Business: A Skill Building Approach. $4^{\text {th }}$ ed., John Willey \& Sons, Inc. New York.

Sohal, A. S., \& Ng, L. (1998). The role and impact of information technology in Australian business. Journal of Information Technology, 13(3), 201-217.

Stank, T. P., Keller, S. B., \& Daugherty, P. J. (2001). Supply chain collaboration and logistical service performance. Journal of Business logistics, 22(1), 29-48.

Sun, Q., \& Tong, W. H. (2003). China shares issue privatization: the extent of its success. Journal of financial economics, 70(2), 183-222.

Tenenhaus, M., Vinzi, V. E., Chatelin, Y. M., \& Lauro, C. (2005). PLS path modeling. Computational Statistics \& Data analysis, 48(1), 159-205.

Terziovski, M., \& Samson, D. (1999). The link between total quality management practice and organisational Performance. International Journal of Quality \& Reliability Management.

Turban, E., Aronson, J.E. \& Liang, T. (2005). Decision Support Systems and Intelligent Systems. $7^{\text {th }}$ ed. Pearson PrenticeHall, Englewood Cliffs, NJ.

Vaidyanathan, R., \& Aggarwal, P. (2005). Using commitments to drive consistency: enhancing the effectiveness of causerelated marketing communications. Journal of Marketing Communications, 11(4), 231-246.

Wang, Y., \& Lee, I. (2013). Visual analytics of higher order information for trajectory datasets. Order, 2(O1VD), O2VD.

Zhang, R., \& Chen, H. (2015). A review of service supply chain and future prospects. Journal of Service Science and Management, 8(04), 485.

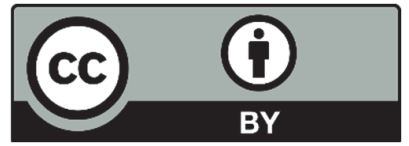

(C) 2021 by the authors; licensee Growing Science, Canada. This is an open access article distributed under the terms and conditions of the Creative Commons Attribution (CC-BY) license (http://creativecommons.org/licenses/by/4.0/). 